\title{
FROM DANGEROUS TO PREVENTIVE, PROTECTIVE AND QUIET DIPLOMACY: THE DOWNTURN IN STATE SOVEREIGNTY AT THE EXPENSE OF INTERNATIONAL HUMAN RIGHTS ENFORCEMENT
}

\author{
Some reflections on Dangerous Diplomacy: \\ The Story of Carl Lutz, Rescuer of 62,000 Hungarian Jews \\ by Theo Tschuy (Eerdmans Publishing Company, \\ Michigan/Cambridge, UK 2000) 265 pp.
}

Peter Ørebech *

\section{Introduction}

The reading of Dangerous Diplomacy, by the historian and theologian Theo Tshuy, prompts reflections on the human rights shift from extra-legal 'individualism' to 'legal institutionalisation', due to the post World War II redefined jus cogens principle of puena erga omnes ${ }^{1}$ and just interventions. While the prime focus during World War II was dangerous rescue operations conducted by 'Righteous Gentiles' like the Swiss Budapest Consul Carl Lutz and his remarkable wife Gertrud, the focus today has changed to preventive, ${ }^{2}$ protective ${ }^{3}$ and quiet diplomacy ${ }^{4}$ under the auspices of the UN, or ultimately by force, engaging UN member states or regional organisations like NATO. ${ }^{5}$ The righteous state and international authorities back up the moral and ethical righteous human. Thus, the fictitious justification of humanitarian intervention in the 1970s by

\footnotetext{
"Professor of law at the University of Tromsø (NFH), Norway.

1 See for instance the Geneva Convention Relative to the Protection of Civilian Persons in Time of War (adopted 12 August 1949, entered into force 21 October 1950) art 33.

2 Boutros Boutros-Ghali, An Agenda for Peace: Preventive Diplomacy, Peacemaking and Peace-keeping (UN, New York 1992). See also Kuman Rupesinghe's proposal of 'Office for Preventive Diplomacy' in Dietrich Fisher (ed), Nonmilitary Aspects of Security: A Systems Approach (UN Institute for Disarmament Research 1993) chapter 5.

3 Robert Johansen, 'Reforming the United Nations to Eliminate War' (1994) 4 (2) Transnational Law and Contemporary Problems 455-502.

4 David Shorr, 'United Nations Reform in Context' (February 2006) The Stanley Foundation Policy Analysis Brief, 5.

5 Use of force is restricted, as indicated in the 1907 Convention on the Peaceful Resolution of International Conflicts, the 1928 Treaty Providing for the Renunciation of War as an Instrument of National Policy (Kellogg-Briand Pact), and the Charter of the United Nations art 33.
} 
reason of self-defence ${ }^{6}$ (UN Charter Article 51) ${ }^{7}$ was, at the end of the millennium, seen as legally valid for the purpose of humanitarian invasion. ${ }^{8}$ Its justification is to be found at the intersection of a modified principle of national sovereignty and the redefined principle of universality, ie the growing international limitations on people's right to self-determination. ${ }^{9}$

A comprehensive, institutionalised system of human rights and universal jurisdiction is underway. ${ }^{10}$ The breakthrough is in the demand for a brand-new version of the 1823 US Monroe Doctrine, ${ }^{11}$ this time in the hands of supra-national institutions, not in the hands of national states, cf the Bush Doctrine: 'Unilaterally if we can, multilaterally if we must'. ${ }^{12}$ As a result, human rights defenders are equipped with a strong interference right as lex superior to the principle of sovereignty.

My reflections on the latest jurisdictional developments in human rights are based on a reading of Dangerous Diplomacy, which recounts the story of Gertrud and Carl Lutz who, faced with humans at risk, let the Swiss diplomatic code and etiquette count, but made Western humanism, ethics and religious conviction (p 28) decide. This fascinating book brings to the forefront interesting puzzles of modern society. One is the story of

\footnotetext{
6 For an analysis of the right to anticipatory self-defense, and pre-emptive strike, see Peter Ørebech, “Anticipatory self-defense”: A pivotal thing in the case of Afghanistan' (under preparation) 7 .

7 Such as the 1971 Indian invasion of Bangladesh and the 1979 Tanzanian invasion of Uganda. See United Kingdom Foreign Office Policy Document no 18, reprinted in Bertram S Brown, 'The Evolving Concept of Universal Jurisdiction' (2001) 35 New England Law Review 383,388 . While the Bush administration presumes that the non UN acknowledged USA-led Iraq invasion is valid self defence, influential US legal scientists challenge that conclusion. See, amongst others, Rex J Zedalis, 'Circumstances Justifying Pre-emptive Self-Defence: Thoughts Prompted by the Military Action Against Iraq' (2005) 74 Nordic Journal of International Law 209-230. For a more general approach to how legal texts 'do more to legitimate than restrain violence', see David Kennedy, 'Modern War and Modern Law' (2007) 16 Minnesota Journal of International Law 493.

8 As was the NATO bombing of Serbia during the 80 days war of 1999. See White House spokesman Joe Lockhart who claimed that NATO's bombing objective was to 'stop the killing and achieve a durable peace' (The Associated Press, March 24, 1999).

9 Corfu Channel [1949] ICJ Rep 4, 22: elementary considerations of humanity are among the general and recognized principles of international law. Barcelona Traction [1970] ICJ Rep 3, 23: The function of the court is 'to confirm and endorse the most elementary principles of morality'. Thus, human rights are among the maxims that form the national sovereignty framework.

10 Jonathan I Charney, 'Universal International Law' (1993) 87 AJIL 529; Antti Korkeakivi, 'Consequences of "Higher" International Law: Evaluating Crimes of State and Erga Omnes' (1996) 2 JILS 81.

11 See Donald Marquand Dozer (ed), The Monroe Doctrine: Its Modern Significance (Alfred A Knopf, New York 1965).

12 See Richard K Betts, 'The political support system for American primacy' (2005) 81 (1) International Affairs 1, 2.
} 
the decline of the 1648 Constitutio Westphalica, the axiom of sovereignty ('Landeshoheit') and non-intervention initiated by the 'first truly European settlement in history, ${ }^{13}$ which came under pressure from a 'modified version of the Monroe Doctrine'.

Another is the transformation of purely moral, ethical and religious principles of human dignity into law. The obligation to resist military orders was fuelled by the 1945-1946 Nuremberg Trial. ${ }^{14}$ The court imposed on the prosecuted Nazi leaders both basic moral and ethical concerns and thereby transformed extralegal principles of righteous and moral behaviour into 'law'. The tribunal's ruling ('law in action'15) 'to confirm and endorse the most elementary principles of morality' ${ }^{16}$ produced binding legal principles. ${ }^{17}$

\section{The Dangerous Diplomacy of individual responsibility}

All human beings bear responsibility for their own decisions and behaviour. Clearly, not all accept that responsibility. If accepted, however, no obligation seems to be more compelling than inter partes moral commitments. ${ }^{18}$ Strictly order-oriented behaviour is insufficient. Every individual suffers from the obligation to resist atrocities:

Rather, his [Keitel's] defence relies on the fact that he is a soldier, and on the doctrine of 'superior orders,' prohibited by Article 8 of the Charter [Nuremberg Court Charter Article 8: 'The fact that the Defendant acted pursuant to order of his Government or of a superior shall not free him from responsibility, but may be considered in mitigation of punishment if the Tribunal determines that justice so requires'] as a defense. There is nothing in mitigation. Superior orders, even to a soldier, cannot be considered in mitigation where crimes as shocking and extensive have been committed consciously, ruthlessly and without military excuse or justification. ${ }^{19}$

\footnotetext{
13 G. Pagès, The Thirty Years War 1618-1648 (Harper \& Row, New York 1970) 228, cf Chapter IX.

14 See the Agreement for the Prosecution and Punishment of the Major War Criminals of the European Axis Powers and Charter of the International Military Tribunal (8 August 1945).

15 Roscoe Pound, Law and Morals (Chapel Hill 1926) 80.

16 Barcelona Traction (n 9) 23.

17 The UN subsequently confirmed the ruling. See UNGA, Affirmation of the Principles of International Law Recognized by the Charter of the Nuremberg Tribunal, 111 December 1945) UNGA Res 95(1) UN Doc A/236 (1946) 1144.

18 This concept is well captured in the film of Patrice LeConte, 'La veuve du Saint-Pierre'.

19 Judgment of the International Military Tribunal for the Trial of German Major War Criminals (1945-46), against the Chief of the High Command of the German Armed Forces, Admiral Keitel.
} 
By rescuing 62,000 Jews from the Nazis during World War II, the Lutz couple took such individual responsibility. ${ }^{20}$ Tschuy asserts that no single person is too insignificant to undertake extraordinary acts of compassion and courage (cf the brave Hungarian Police Captain Kalman Horvath (p. 99) and the Romanian diplomat Florian Manoliou (p 142)). Individuals are capable of principled, selfless action. As decent humans, the Lutzes' only choice was to save innocent lives, irrespective of whether this represented disobedience to diplomatic protocols: 'Were they [the refugees] not like Lazarus, the poor man on the steps, and was he [Lutz] not to them like the rich man?' (p 41). The Lutzes took responsibility far beyond diplomatic obligations.

Righteous treatment of others requires personal high moral standards. Religious beliefs alone do not count for decent human behaviour. The Holocaust that Lutz the Methodist ('in his youthful enthusiasm he wanted Jesus to guide his life' (p 27)) fought so hard against was tacitly supported by the Hungarian Catholic Church (cf leader Cardinal Jusztitian Serédi (p 114)), at least until August 1944 (p 164). Obviously, religion may mandate decency, but personal ethical conviction determines personal choices.

In a situation of conflicting moral and legal norms, individuals are faced with impossible choices. Only the strongest proselytes and cleverest strategists survive in such a climate. Lutz did so; he transgressed diplomatic codes and etiquette, which made the Swiss Foreign Ministry call him before an investigating judge (p 260). Where 'diplomatic custom [clashed] with human considerations' (p 16) Lutz took a disobedient role similar to the one that the post-war Court of Nuremberg urged Nazi criminals to take. Practising (in time of war) the emerging conventional protection of the 'right to life', Lutz met what later became the expectations of Article 3 of the 1948 Universal Declaration of Human Rights. He naturally responded in a humane manner, confronted as he was with individual and family tragedies at close hand ('it was he who had to look into the faces that were distorted by fear, day after day' (p 68)). His only choice was to issue Swiss 'Schutzbriefe' to Jews at risk, granting Swiss immunity (p 67) and making arrangements for safe rescue abroad. The magical limit of 8,000 protection letters (negotiated with the Hungarian and German authorities) was, however, far exceeded by Lutz's practice of issuing duplicate protection letters, numbered below 8,001. The author estimates that Lutz, in total, issued approximately 80,000 'Schutzbriefe' (p 89). Through this tactic, 62,000 Jews were rescued.

\footnotetext{
20 Another example of a 'righteous human' is the Czech Sudeten-German industrialist and Nazi member Oskar Schindler, in Stephen Spielberg's film, 'Schindler's List,' who managed to rescue approximately 6,000 Polish Jews.
} 
The only public response Lutz received after the war was a formal reprimand! In 1995, twenty years after Lutz's death, the Swiss Federal Government officially apologised for its long neglect, declaring Carl Lutz to be one of the outstanding citizens in the nation's history (Foreword by Simon Wiesenthal p xii). Faced with bureaucratic condemnation and loss of professional credibility, few people choose the ethical option that conflicts with legal provisions. Public servants with a weaker character than Carl Lutz will surely back off. A viable system of human rights cannot survive under such harsh conditions. Only through the backing of codification, surveillance and control ('legal institutionalisation') will individual morals succeed. In a world of politically initiated atrocities, individual responsibility and plain righteousness are insufficient.

\section{Immoral and unethical behaviour on display}

Another insight from the book is that the Nazis preferred to pursue their cause in secret. No effort was spared to disguise their atrocities. Confronted with the 'rumours', SS leaders vehemently rejected the genocide accusations as 'wild imagination' (p 133). Jewish leaders misinterpreted the situation and chose inappropriate strategies such as cooperation with the Nazis and buy-out schemes to rescue endangered Jews from death camps (see the harsh criticism of Reszö Kasztner (pp 84 and 133) and the Jewish Council of Hungary (p 80)). By sending the Auschwitz Protocols, written by the Slovak Jews Rudolf Vrba and Josef Lanik who miraculously escaped the death camp, to the Jewish-born Salvadoran Consulate Administrator in Switzerland, George Mandel-Mantello, Lutz helped to break the silence and expose the Nazi criminal offences. Mandel-Mantello spread the news so that 'the spirit released ...could not be squeezed back into the bottle again' (p 142). Under the scrutiny of a free press and world opinion, fear of universal outrage would possibly hold back even the worst mass murderer from pursuing his purposes. The aftermath of this publication was the miraculous end to Jewish deportation with the decree of 8 July 1944 of the Hungarian regent, Nicolas Horthy, which outraged Adolf Eichmann and the German Ambassador to Hungary, Edmund Veesenmayer (p 147).

The importance of reliable information cannot be underestimated; some say that the 'the pen is mightier than the sword'. Clearly, a free press and freedom of expression are well provided for under Article 19 of the 1948 Universal Declaration of Human Rights and the corresponding principles enumerated in the 1966 International Covenant on Civil and Political Rights. Even more important to guarantee favourable conditions for the operation of the mass media is the 1978 Declaration on Fundamental Principles concerning the Contribution of the Mass Media to Strengthening Peace and International Understanding, to the Promotion 
of Human Rights and to Countering Racialism, Apartheid and Incitement to War. ${ }^{21}$ Even though openness of governance is provided, one cannot do without a free and independent press.

\section{Those who cannot remember the past are condemned to repeat it}

Another image that Dangerous Diplomacy leaves with the reader is that life experience imprints unbreakable patterns on legal development. Before World War II, the racially persecuted enjoyed no conventional protection. The book provides insight into the historic events that 'fuelled the engine' of the 1948 Human Rights Declaration, the 1948 Convention on the Prevention and Punishment of the Crime of Genocide (Genocide Convention), ${ }^{22}$ the 1949 Conventions on the Protection of War Victims, and the 1950 European Convention on Human Rights. These experiences explain why Article 1 of the Declaration reads 'All human beings are born free and equal in dignity and rights' and Article 2 'Everyone is entitled to all the rights and freedoms set forth in this Declaration, without distinction of any kind, such as race...social origin... birth or other status.'

One lesson of World War II is to expose the risk run in placing one's trust in 'righteous gentiles' worldwide. Even if the human spirit is good, we must recall that human commitments are weak. 'I concur with Hobbes in assuming that no bottom-up mechanism of order is capable of preventing war under anarchy. ${ }^{23}$ This warning is displayed under human rights violations as well. Righteous humans need strong institutional support to survive in a society ignorant of human rights. ${ }^{24}$

\section{Towards preventive and protective diplomacy under the auspices of the UN}

Dangerous Diplomacy demonstrates that legislation and conflict resolution or prosecution are only one step in criminal procedure. Just implementation through enforcement is also important, as illustrated by

\footnotetext{
21 UNESCO General Conference $\left(22\right.$ November 1978) $20^{\text {th }}$ session, Paris; UNESCO's Standard-Setting Instruments (1994) IV C.

22 The convention is displayed by the International Court of Justice (Croatia $v$. Yugoslavia). On 2 July 1999 the Republic of Croatia instituted proceedings before the Court against the Federal Republic of Yugoslavia for violations of the 1948 Genocide Convention alleged to have been committed between 1991 and 1995. Cf 1951 ICJ 15, Advisory Opinion of 28 May 1951: Reservations to the Convention on the Prevention and Punishment of the Crime of Genocide.

23 Raino Malnes, The Hobbesian Theory of International Conflict (Scandinavian University Press 1993) 36. See also David Fisher, 'The Ethics of Intervention and the Former Yugoslavia' in Roger Williamson (ed), Some Corner of a Foreign Field (Basingstoke 1998) 166-173.

24 As stated by Charlotte Bunch at the Harvard Human Rights Journal Spring Conference on UN Reform and Human Rights (25 February 2006), conceptualising and organising for human rights is the alpha \& omega in the struggle for human rights protection.
} 
the post-war scandalous pressure by the US High Commissioner for Germany, John McCloy, to pardon Veesenmayer from a mild 20-year prison sentence after having served only 5 years. In the fight against communism, no sacrifice of Jewish lives was too nasty. Veesenmayer had 'succeeded in using this new spirit to reduce the enormity of his crime' ( $p$ 216).

To achieve the goal of viable human rights protection, a comprehensive system of human rights institutions is needed, including internationally recognised lawmakers, direct law applicability (monistic international law obligations), and international institutions' enforcement and conflict resolution capabilities. The time has passed for the inadequate individual level responsibility of the early to mid 1900s.

Since 1945, the establishment of international institutions with legal personality has been a major revolution in international law. The following are some of the human rights highlights of the past half-century: first and foremost is the evolving conventional human rights obligations, as mentioned above. Most instruments impose worldwide, universal obligations. These international instruments are supplemented by numerous UN human rights declarations and resolutions. ${ }^{25}$ The development and refinement of human rights obligations by human rights institutions has set the agenda for the future. Due to the interpretative implementing and recommending power of the High Commissioner for Human Rights, new standards may be developed quite independently of the tyranny of nation states. ${ }^{26}$ The Security Council may adapt to these standards. An important illustration is the 1994 resolution emphasising that the practice of 'ethnic cleansing' is a clear violation of international humanitarian law. ${ }^{27}$

Through the redefinition of universality, the territorial scope of national legislative competency belongs to the exclusive autonomy of the state. ${ }^{28}$ For instance, Serbian breaches of US or Western European human rights principles in the now former Serbian province of Kosovo may be an offence against US and Western European law. While the principles of territory and nationality are well recognised, state competency beyond national boundaries vis-à-vis foreign citizens abroad traditionally

\footnotetext{
25 The United Nations and Human Rights 1945-1995 (UN Blue Book Series vol VII, New York 1996).

26 Felice Gaer, 'Reality Check: Human Rights NGOs Confront Governments at the UN' in Thomas Weiss \& Leon Gordenker (eds), NGOs, the UN and Global Governance (Boulder Colorado 1996).

27 S/RES/941(23 September 1994).

28 The Danish professor of law Alf Ross did point to this option in the early 1950s: Alf Ross, Dansk Statsforfatningsret [Danish Constitutional Law]bd. I, 2nen udgave (Nyt nordisk forlag, København 1966) 18. See also Henrik Zahle, Dansk Statsforfatningsret [Danish Constitutional Law] bd. I (Christian Ejlers' Forlag, København 1989) 92.
} 
requires some sort of threat to state interests. ${ }^{29}$ The 'Lotus-case'30 already shows that penal offences by foreigners abroad may be a breach of the criminal laws of third states.

Secondly, human rights have been strengthened by the development of a permanent international system of human rights adjudication. The 1950 European Human Rights Court, the International Criminal Tribunal for the former Yugoslavia, ${ }^{31}$ and the Rwanda Tribunal ${ }^{32}$ followed the early ad hoc International Military Tribunals of Nuremberg and Tokyo. The new UN Human Rights Council ${ }^{33}$ and the International Criminal Court of Rome (ICC) ${ }^{34}$ have finally joined in.

Besides the new courts, the UN Human Rights Committee [now Council], according to the 1966 Covenant on Civil and Political Rights Article 28, cf. article 41 and the Optional Protocol which install the committee with justification competency, has a role in the adjudication of human rights. ${ }^{35}$ And even more important, the 1948 Genocide Convention obliges Member States Courts (art 1) to apply human rights principles. If not prosecuted 'at home,' an international penal tribunal (art 6) may pursue the case against alleged violators. Whether external national courts may apply the genocide obligations to foreign citizens conducting atrocities abroad is to be considered by these courts under the national application of the principle of universality. The arrest and now terminated

\footnotetext{
${ }_{29}$ De lege lata several understandings have been advocated. For my purpose, no detailed discussion is necessary. See, however, Kenneth C Randall, 'Universal Jurisdiction under International Law' (1988) 66 Texas Law Review 785.

30 PCIJ Series A No 10 (1927).

31 Secretary Council resolution adopting the Statute of the International Tribunal for the Prosecution of Persons Responsible for Serious Violations of International Humanitarian Law Committed in the Territory of the Former Yugoslavia since 1991 (25 May 1993) S/RES 827.

32 Secretary Council resolution containing the decision to establish an international tribunal for the prosecution of persons responsible for genocide and other serious violations of international humanitarian law committed in Rwanda or in the territory of neighboring States (8 November 1994) S/RES 955.

33 For a short and informative overview, see Shorr (n 4) 5-6.

34 Rome Statute of the International Criminal Court of July 17, 1998 (at present 27 Member States, in effect by the $60^{\text {th }}$ ratification): competency is limited to prosecution and conviction of persons for genocide, crimes against humanity and war crimes. Norway for instance has implemented the ICC obligations into domestic law. See Odelstingsproposisjon (Ot.prp.) nr. 24 (1999-2000) Om ratifikasjon av Roma-statutene til Den Internasjonale Strafferettsdomstol av 17 july 1998 [Ratification of the Rome statute of the International Criminal Court] Chapter 2. Whether the court will enjoy jurisdiction over citizens of non-member states is discussed in Jordan J Paust, 'The Reach of ICC Jurisdiction Over Non-Signatory Nationals' (2000) 33 Vanderbilt Journal of Transnational Law 1.

35 One illustration is the ICJ Order of 21 February 2001 in the case concerning the legality of use of force (Yugoslavia $v$. Belgium), since the justification of the NATO bombing is related to criminality against humanity. Similar cases are raised against other NATO countries that participated in the attacks.
} 
prosecution of Slobodan Miloševi signalled that even a top state executive performing genocide or 'ethnic cleansing' is responsible towards the international societies of states.

Third, the protection of human rights is dependent on a proper system of surveillance, control and enforcement. If military, paramilitary or police forces carry out atrocities against their own citizens, humanitarian intervention and enforcement is an international concern. Such intervention is performed by UN-sanctioned military actions, or if the General Assembly or the Security Council fails to submit peacekeeping or military forces, by voluntary forces mounted by UN member states, if none of the Security Council States objects. An UN-external solution may be found under the auspices of regional or international defence agencies such as the North Atlantic Treaty Organization (NATO) of 4 April 1949 as extended by the Act of $1997 .{ }^{36}$ It is said that NATO operations are "the logical extension of the principle of the Monroe Doctrine. ${ }^{37}$

NATO addresses the inability of the UN Security Council or the General Assembly to act properly, taking military responsibility for the human rights situation. ${ }^{38}$ Even some right of anticipatory action has been considered. ${ }^{39}$ Surely this 'extension' clashes with former understandings of the concept of sovereignty. ${ }^{40}$ However, there is a fine balance between the notion of sovereignty and the development of inalienable human rights. As stated by the Swedish Professor of law, Torsten Gihl:

International customary law is in constant development, and a unilateral decision contrary to established practices, which in the first run indicates a breach of international law, may simply be the signs of a new International Law. ${ }^{41}$

This is precisely what Professor Charney predicts:

Perhaps the Kosovo intervention sets a precedent for the development of new international law to protect human rights. After all,

\footnotetext{
36 NATO, Founding Act on Mutual Relations, Cooperation and Security between NATO and the Russian Federation , Paris, 27 May 1997.

37 The observation by Senator Tom Connolly as referred to by Thomas G Paterson, On Every Front: The Making of the Cold War (Norton, New York 1979) 67.

38 Dick A Leurdijk, 'Before and after Dayton: the UN and NATO in the former Yugoslavia' in Thomas G Weiss (ed), Beyond UN Subcontracting (Basingstroke, 1998) 49-66.

39 Christopher C Joyner \& Anthony Clark Arend, 'Anticipatory Humanitarian Intervention: An Emerging Legal Norm?' (1999/2000) 10 Journal of Legal Studies 27.

40 Klinton W Alexander, 'NATO's intervention in Kosovo: the Legal Case for Violating Yugoslavia's National Sovereignty in the Absence of Security Council Approval' (2000) 22 (3) Houston Journal of International Law 403-449.

${ }^{41}$ Torsten Gihl, 'Aktuella problem inom folkrätt och allmän rättslära' [Present problems in international law and legal theory] (1953) Svensk juristtidning 356, 366. Author's translation.
} 
general international law may change through breach of the current law and the development of new state practice and opinio juris supporting the change. ${ }^{42}$

Such a possible transformation was initiated by the new NATO policy of the late 1990s:

NATO has expanded and will continue to expand its political functions, and taken on new missions of peacekeeping and crisis management in support of the United Nations (UN) and the Organisation for Security and Cooperation in Europe (OSCE). ${ }^{43}$

In the case of Yugoslavia, NATO, despite the lack of any UN decisions, pursued its 'crisis management mission.' This poses the question of whether tacit UN recognition is sufficient. It also suggests that human rights defence is no longer the sole cause of toothless UN resolutions. Today, it may be asked whether the nation state sovereignty axiom of non-interference, coupled with incomplete international enforcement, is on the brink of failure when it comes to human rights defence. Some would say that fundamental human rights have become jus cogens, ie a non-derogative principle of customary international law. ${ }^{44}$ With support in the International Court of Justice 1951 advisory opinion, this is not a far-flung option.

It may be asked whether the Constitutio Westphalica principle of sovereignty is limited to states that implement, and do not breach, their international human rights obligations. This is not a remote wish, but seems to have strong support in US foreign policy, cf the 1992 statement by Richard C. Holbrooke (who soon after became Assistant Secretary of State in the Clinton administration):

A new principle of international relations is arising: the destruction or displacement of groups of people within states justifies international intervention. A new balance must be struck between traditional sovereignty and the world community's interest in human rights. ${ }^{45}$

In the former Yugoslavia, the intervention scheme has taken a further step since the recommendation of NATO air strikes without prior UN Security Council authorisation significantly challenged the established

\footnotetext{
42 Jonathan I Charney, 'NATO's Kosovo Intervention: Anticipatory Humanitarian Intervention in Kosovo' (1999) 93 (4) AJIL 834, 836.

43 NATO, Founding Act on Mutual Relations, Cooperation and Security between NATO and the Russian Federation, Paris, 27 May 1997.

44 See Fernando R Teson, Humanitarian Intervention: An Inquiry Into Law and Morality (Dobbs Ferry, New York 1988).

45 Carnegie Endowment for International Peace National Commission, Changing Our Ways: America and the New World (Carnegie Endowment for International Peace, Washington DC 1992) 51.
} 
international legal order. ${ }^{46}$ The NATO response ranked the principles of humanitarian intervention above the norms of state sovereignty (according to UN Charter Article 2(4): 'All members shall refrain in their international relations from the threat or use of force against the territorial integrity or political independence of any state'). Even though NATO practice seems to advocate that a regional organisation rather than the Security Council may be the final arbiter, such a position is highly debatable. The validity of the NATO actions, a question put before the International Court of Justice in the Hague, ${ }^{47}$ depends on whether the danger was real and immediate and there were no other ways to avert the danger (Customary International Right of Self-Preservation). Even though the weakest point for the human rights cause pursued by NATO is the lack of UN express acknowledgment, it is not clear that the non-intervention and sovereignty principle will gain support in the Hague proceedings. It might be advocated that the UN Charter Article 2(4) is vested in law-abiding states only, cf the Corfu Channel Case stating that elementary considerations of humanity are among the general and recognised principles of international law. ${ }^{48}$ The UN Charter's protection of sovereignty requests that such elementary considerations are defended by UN Member States.

An additional argument is that the military mission was not contrary to any decision made either by the Security Council or the General Assembly. Some would probably say that the Security Council, in demanding ceasefires and the termination of criminal acts, created an opening for military action. The UN, acting under Chapter VII of the Charter of the United Nations, stated in a 1998 resolution on Kosovo that the Security Council:

Decides, should the concrete measures demanded in this resolution and resolution 1160 (1998) not be taken, to consider further action and additional measures to maintain or restore peace and stability in the region. ${ }^{49}$

This strong concern was further expressed later that year:

Deeply alarmed and concerned at the continuing grave humanitarian situation throughout Kosovo and the impending humanitarian catastrophe, and re-emphasizing the need to prevent this from happening. ${ }^{50}$

\footnotetext{
46 The inherent right is an alternative to codified law, see Ørebech (n 6) 7.

47 See ICJ Order ( $\mathrm{n}$ 35). The court had earlier rejected by clear majorities to give intermediate relief in favour of Yugoslavia. See the International Court of Justice (ICJ) decision of 2 June 1999, requests filed by Yugoslavia against ten NATO member states on 29 April 1999, asking the ICJ to order the NATO members to 'cease immediately [their] acts of use of force' and to 'refrain from any act of threat or use of force' against Yugoslavia.

48 ICJ (1949) 22.

49 UN Doc (September 23, 1998) S/RES/1199, emphasis added.

${ }^{50}$ Security Council Resolution 1203 (1998) on the situation in Kosovo, UN Doc. S/ RES/1203.
} 
But such strong expressions of concern did not stop Serbian atrocities. Was military action the only 'further action and additional measures' left (see UN Charter 42)? Since the ICJ found valid the US reservations to the court's jurisdiction under the Genocide Convention that Yugoslavia accused the US of breaching, ${ }^{51}$ the ICJ dismissed the case, and we will thus not know the answer to that question.

One line of argument goes as follows: during the NATO bombing operations in Serbia, the Security Council, at its Kosovo meeting of 14 May 1999, did not ban the NATO mission. ${ }^{52}$ And in that connection, Yugoslavia itself has clearly documented 'ethnic cleansing,' genocide, and other atrocities in Kosovo. ${ }^{53}$ It is difficult to say what the court ruling would have been. ${ }^{54}$

\section{Postscript}

Dangerous Diplomacy illustrates why freedom of speech, a free press, critical opposition and self-reliant citizens with no fear of the high and mighty are the alpha \& omega of all societies (p 262). Even though some success is achieved in creating human rights institutions, we still need the 'righteous' to prevent human rights abuses on a daily basis. Preventive diplomacy ex ante by implemented internalised human rights protection is clearly preferable ex post facto to military protective diplomacy.

Enjoying, for the first time in history, strong support from the international society of states, righteous individuals have a supportive environment that may encourage the human rights cause. Theo Tschuy's book deftly illustrates how righteous human morals have evolved into legal obligations, and shows why human rights issues have become firmly entrenched in political life worldwide.

\footnotetext{
51 Legality of Use of Force (Yugoslavia v. US) (June 2 1999) ICJ 916.

52 Security Council Resolution 1239 (1999) on Security Council resolutions 1160 (1998), 1199 (1998) and 1203 (1998), UN Doc. S/RES/1239.

53 OSCE, Kosovo/Kosova, As Seen, As Told: An Analysis of the Human Rights Findings of the OSCE Kosovo Verification Mission October 1998 to June 1999'.

54 Quite a few legal scientists object to the validity of the intervention. See Dale Carson, 'Contemporary International Law Issues: The Kosovo Question' (2000) 2 Florida Coastal Law Journal 167, with further references. A more positive attitude to the NATO mission is found in Charney (n 42).
} 